\title{
Growing Periandra mediterranea on post-mining substrate: native Fabaceae with potential for revegetation of degraded rupestrian grasslands in Brazil
}

\section{Maurilio Assis Figueiredo ${ }^{1 *}$, Adriana Pedrosa Diniz , Adriana Trópia de Abreu1', Maria Cristina Teixeira Braga Messias $^{2}$ and Alessandra Rodrigues Kozovits ${ }^{2}$}

Received: November 3, 2017

Accepted: November 29, 2017

\begin{abstract}
Recovery of degraded areas of rupestrian grasslands is hampered mainly by the limited knowledge regarding substrate management and the biology of native species suitable for revegetation of these areas. The aim of our study was to examine the establishment and growth of Periandra mediterranea in different textures of lateritic substrate from a mining-degraded area. The growth of $P$. mediterranea was evaluated using fine and coarse laterite, both with and without the addition of topsoil. Survival, dry biomass, content of chemical elements and nodulation were evaluated in ten individuals per treatment sixteen months after planting. Although the substrate has low nutrient content, yet high metal concentrations, all plants survived. Plants growing on coarse laterite had $140 \%$ greater biomass than those growing on fine laterite. The addition of topsoil increased biomass in coarse and fine laterite by 46 and $151 \%$, respectively, and doubled the number of nodulated plants, regardless of grain size. The biomass accumulation of $P$. mediterranea to a dystrophic substrate revealed its potential for use in the revegetation of degraded areas of rupestrian grasslands. Furthermore, the addition of topsoil facilitated the association of P. mediterranea with nitrogen-fixing bacteria, and increased its growth and capacity to improve substrate fertility.
\end{abstract}

Keywords: bauxite, canga, Leguminosae, recovery of degraded areas, rock outcrops, topsoil

\section{Introduction}

Brazilian rupestrian grasslands, which have been considered biodiversity hotspots, harbor a significant number of species of the diversified Brazilian flora (Myers et al. 2000; Silveira et al. 2015). However, these areas have been constantly impacted by several anthropic activities (Kolbek \& Alves 2008; Barbosa et al. 2010; Fernandes et al. 2014; Veldman et al. 2015). Therefore, the demand for mitigation and minimization of these impacts is high
(Sonter et al. 2014). One of the ways to reduce damage to rupestrian grasslands, yet maintain anthropic activities important to the country's economy such as mining, is through the recovery of degraded areas. However, ecological restoration of degraded areas of rupestrian grasslands is hampered mainly by a the lack of knowledge about appropriate management techniques that could enhance the physical and chemical characteristics of substrates and limited knowledge about the biology of native species suitable for the revegetation of these areas (Figueiredo et al. 2012; Silveira et al. 2015; Fernandes et al. 2016).

1 Departamento de Geologia, Universidade Federal de Ouro Preto, Campus Morro do Cruzeiro, 35400-000, Ouro Preto, MG, Brazil

2 Departamento de Biodiversidade, Evolução e Meio Ambiente, Universidade Federal de Ouro Preto, Campus Morro do Cruzeiro, 35400-000,

Ouro Preto, MG, Brazil

* Corresponding author: maurilioafigueiredo@gmail.com 
The limited knowledge about native plant species that are suitable for revegetation of degraded areas of rupestrian grasslands has resulted in the widespread use of exotic species for this purpose, especially fast growing grasses and legumes. However, many of these species are invasive and affect local biodiversity (Barbosa et al. 2010; Hilário et al. 2011; Fernandes et al. 2015). Several studies have attempted to improve knowledge regarding the reproductive biology and establishment of native species with potential application in the revegetation of degraded areas of rupestrian grasslands (Garcia et al. 2006; Negreiros et al. 2009; Figueiredo et al. 2012; Rodrigues \& Silveira 2013). However, few studies have evaluated the establishment and growth of species on degraded substrates or in field conditions. Moreover, few works have been successful in establishing and growing native species in degraded areas of rupestrian grasslands. This low success rate is mainly due to substrate conditions, such as low water retention, compaction, nutrient deficiency and high concentration of toxic elements (Stradic et al. 2014a; b; 2015).

In an attempt to overcome the inhospitable characteristics of substrates of impacted areas of rupestrian grasslands, techniques have been used that have been applied in the recovery of degraded areas in other environments, such as fertilization and acidity correction. However, nutrient enrichment of the poor substrate of savannas, especially with phosphorus, may be detrimental to some native species that are adapted to soils with low fertility (Lambers et al. 2015) and can facilitate the establishment and growth of exotic and invasive species (Barbosa et al. 2010; Bustamante et al. 2012).

Recovery projects for degraded areas of rupestrian grasslands using native species, and adjusting the texture of substrates to make them more similar to those of reference areas, have been successful at facilitating plant establishment, root development and water percolation (Machado et al. 2013; Figueiredo et al. 2015). These results indicate the need for detailed investigations in search of plant species tolerant to the chemical conditions of the substrate of degraded areas, and for proposing interventions in the physical characteristics (grain size) of the substrate in order to facilitate plant establishment. In addition, floristic and ecological studies of reference areas in rupestrian grasslands are important tools for the development of strategies that can contribute to the recovery of degraded areas in these environments (Fernandes et al. 2016).

Several phytosociological studies of rupestrian grasslands have observed high diversity and abundance of legumes (Oliveira \& Godoy 2007; Messias et al. 2012; Silva \& Martins 2013; Messias \& Carmo 2015). The success of legumes in rupestrian grasslands is due, in part, to their association with nitrogen-fixing bacteria, which increase the availability of this element to plants since its concentrations in soils of rupestrian grasslands are low (Vincent \& Merguro et al. 2008; Messias et al. 2013). This information leads us to believe that the use of legumes native to rupestrian grasslands, together with actions that facilitate the association of these plants with microorganisms, can help re-colonization of degraded substrates by these plants and contribute to improving fertility in the long term.

Due to the incipient knowledge regarding legumes and nitrogen-fixing bacteria of rupestrian grasslands, strains of nitrogen-fixing bacteria from these areas are not yet available. It is presumed that the association between some legumes and nitrogen-fixing bacteria in poor soil environments, such as rupestrian grasslands, also depends on the association of plants with mycorrhizal fungi (Oliveira et al. 2016). Therefore, it is believed that an affordable way to promote the association between nitrogen-fixing bacteria and legume species in substrates of degraded areas is by the addition of small amounts of topsoil from preserved areas of rupestrian grasslands to the substrate of areas to be revegetated.

For the selection of species with potential for use in the recovery of degraded areas, it is advisable to prioritize native species that are abundant in environments with edaphic conditions similar to those found in degraded areas (Madejón et al. 2003; Fernandes et al. 2015). Periandra mediterranea is a shrub legume native to rupestrian grasslands that possesses the previously mentioned features (Funch \& Barroso 1999; Viana \& Lombardi 2006; Mourão \& Stehmann 2007; Messias et al. 2012), which makes it a promising species for the revegetation of degraded areas, as indicated by Lima et al. (2016).

In addition to the ecophysiological characteristics that make $P$. mediterranea a candidate for application in the recovery of degraded areas, the species also has economic importance due to its anti-inflammatory properties (Pereira et al. 2000). The use of species of economic value in the recovery of areas degraded by mining is desirable and recommended by the Brazilian legislation (COPAM 2008), as it allows the sustainable exploitation of the area after the mining activity.

In addition to its abundance in rupestrian grasslands, P. mediterranea is also found in the Amazon, Cerrado, Caatinga, Atlantic Forest, and sandbank areas and occurs naturally in all regions of Brazil and parts of Bolivia. Periandra mediterranea is mostly found in environments at elevations between 400 and $800 \mathrm{~m}$ and on sandy soils, latosols and rocky outcrops (Funch \& Barroso 1999; Groom 2012; Queiroz 2016). The adaptation of this species to environments with dystrophic soils is possibly due, in part, to its ability to establish associations with nitrogen-fixing bacteria (Menéndez et al. 2016) and mycorrhizal fungi (Lima 2014).

In view of the above, the aims of this study were to: (i) evaluate the growth of $P$. mediterranea on substrates from an area degraded by bauxite mining; (ii) determine which substrate texture promotes better plant growth; (iii) determine if the addition of small portions of topsoil from 
a preserved area will influence the number of plant nodules and their growth; and (iv) evaluate the concentration of nutrients and potentially toxic elements in individuals of P. mediterranea exposed to different treatments.

\section{Materials and methods}

\section{Collection and preparation of substrates}

Seeds, topsoil and laterite blocks used in this study were collected at "Cachoeira das Andorinhas" State Environmental Protection Area (APA), municipality of Ouro Preto, Minas Gerais, Brazil. The materials were collected from an area between 1400 and $1500 \mathrm{~m}$ a.s.l. According to the Koppen classification (Alvares et al. 2014), the climate in the region is Cwb, mesothermic moist, with dry winters and mild rainy summers.

Laterite blocks were collected from an abandoned area degraded by bauxite mining $\left(20^{\circ} 21^{\prime} \mathrm{S} 43^{\circ} 30^{\prime} \mathrm{W}\right)$. After the collection, using a jaw crusher, the blocks were fragmented into two distinct textures: fine and coarse laterite (Tab. 1). Five samples of each texture were collected for analysis of grain size and total and available concentrations (fertility) of chemical elements.

Grain size analysis followed the methodology described in Figueiredo et al. (2015). The total concentration of elements was determined according to Moutte (2009). Fertility analyses were performed according to methodology described by Embrapa (1997). Characterization of the substrates is shown in table 1.

Substrates were distributed into 40 cylindrical vessels (30 $\mathrm{cm}$ in height and $30 \mathrm{~cm}$ in diameter), with each vessel receiving 12 liters of substrate. In 10 of vessels for each type of substrate, a small depression was made on the substrate surface in which $50 \mathrm{ml}$ of topsoil was deposited. This superficial soil was collected from a preserved ferruginous rupestrian grassland (around the point 20 21'29"S $43^{\circ} 30^{\prime} 10^{\prime \prime}$ ) of "Serra da Brígida", also in "Cachoeira das Andorinhas" APA. Approximately $100 \mathrm{~mL}$ of topsoil was collected at 10 randomly chosen points separated by a minimum of 10 meters, for a total of $1000 \mathrm{~mL}$. The soil was then homogenized and evenly distributed among 20 treatment vessels (50 $\mathrm{mL}$ per vessel).

\section{Plants}

Periandra mediterranea (Vell.) Taub seeds that were collected in the same area where the topsoil was collected were placed to germinate in an equal volume mixture of vermiculite and sand. When seedlings reached about 10 $\mathrm{cm}$ in total length (shoots and roots) and possessed four leaves, they were transplanted to 40 vessels, thus comprising four treatments of a factorial experiment: coarse laterite (CL), fine laterite (FL), coarse laterite with topsoil (CLT) and fine laterite with topsoil (FLT). After planting, the vessels were kept in a greenhouse under natural light and controlled temperature $\left(25^{\circ} \mathrm{C}\right)$ and humidity $(60 \%)$, with daily irrigation with $3 \mathrm{~mm}$ of water.

Individual plants were collected sixteen months after planting. All substrate adhered to the root system was carefully removed with the aid of a water jet. Fresh roots were scanned using a digital scanner (Epson 11000), and their length, diameter, volume and surface area determined by analyzing the resultant images using Winrhizo arabidopsis ${ }^{\circledR}$ software.

Table 1. Mean values for fertility, total concentration of chemical elements and percentage of grain-size fractions in laterite substrates from area degraded by bauxite mining in Ouro Preto, Minas Gerais, Brazil. Values for fertility and total concentration of chemical elements were the same for coarse and fine laterite.

\begin{tabular}{|c|c|c|c|c|c|c|c|c|c|c|c|c|c|}
\hline \multicolumn{14}{|c|}{ Fertility } \\
\hline $\mathrm{pH}$ & $\mathrm{OM}$ & $\mathrm{N}$ & \multirow{2}{*}{$\begin{array}{l}\text { P-rem } \\
\mathrm{mg} \mathrm{l}^{-1}\end{array}$} & $\mathrm{P}$ & K & $\mathrm{Ca}^{2+}$ & $\mathrm{Mg}^{2+}$ & $\mathrm{H}+\mathrm{Al}$ & SB & CTC ef. & CTC pH 7 & $\mathrm{~V}$ & $\mathrm{~m}$ \\
\hline & \multicolumn{2}{|c|}{ dag $\mathrm{kg}^{-1}$} & & \multicolumn{2}{|c|}{$\mathrm{mg} \mathrm{dm}{ }^{-3}$} & \multicolumn{6}{|c|}{$\mathrm{cmol} \mathrm{dm} \mathrm{m}^{-3}$} & \multicolumn{2}{|c|}{$\%$} \\
\hline 5.04 & 1.04 & 0.04 & 19.22 & 1.4 & 12.2 & 0.15 & 0.05 & 2.32 & 0.23 & 0.23 & 2.55 & 9.14 & 0 \\
\hline \multicolumn{14}{|c|}{ Total Concentration } \\
\hline \multicolumn{7}{|c|}{ Macronutrients $\left(\mathrm{mg} \mathrm{kg}^{-1}\right)$} & \multicolumn{7}{|c|}{ Micronutrients $\left(\mathrm{mg} \mathrm{kg}^{-1}\right)$} \\
\hline & $\mathrm{Ca}$ & $\mathrm{Mg}$ & K & $\mathrm{P}$ & $S$ & & & $\mathrm{Cu}$ & $\mathrm{Fe}$ & $\mathrm{Mn}$ & Mo & $\mathrm{Zn}$ & \\
\hline & 143 & 267 & 366 & 439 & 402 & & & 21 & 210646 & 541 & 5.4 & 43 & \\
\hline \multicolumn{14}{|c|}{ Non-essential Elements ( $\mathrm{mg} \mathrm{kg}^{-1}$ ) } \\
\hline $\mathrm{Al}$ & $\mathrm{Ba}$ & As & Co & $\mathrm{Cr}$ & $\mathrm{Ni}$ & Sc & $\mathrm{Sr}$ & Th & $\mathrm{Ti}$ & V & $\mathrm{Y}$ & $\mathrm{Zr}$ & \\
\hline 208366 & 32 & 73 & 22 & 336 & 21 & 18 & 90 & 47 & 16559 & 404 & 26 & 455 & \\
\hline \multicolumn{14}{|c|}{ Grain Size (\%) } \\
\hline & & & CGR & GR & VCS & CS & MS & FS & VFS & S/A & & & \\
\hline & & $C L$ & 29 & 16 & 12 & 10 & 9 & 8 & 7 & 9 & & & \\
\hline & & FL & 2 & 20 & 16 & 13 & 10 & 13 & 11 & 15 & & & \\
\hline
\end{tabular}

OM - organic matter, P-rem - remnant phosphorus SB - sum of bases, CTCef - effective cation exchange capacity, CTCpH7 - cation exchange capacity in $\mathrm{pH} 7.0, \mathrm{~V}$ - base saturation, $\mathrm{m}$ - Aluminum saturation. CL - coarse laterite, FL - fine laterite, CGR - coarse gravel ( $>4 \mathrm{~mm})$; GR - gravel ( $>2 \mathrm{~mm})$; VCS - very coarse sand ( $>1 \mathrm{~mm})$; CS - coarse sand $(>0.5 \mathrm{~mm}), \mathrm{MS}-$ medium sand $(>0.25 \mathrm{~mm})$, FS - fine sand $(>0.125 \mathrm{~mm})$; VFS - very fine sand $(>0.063 \mathrm{~mm}) ; \mathrm{S} / \mathrm{A}$ - silt and clay $(<0.063 \mathrm{~mm})$. Grain size fraction classification was based on Wentworth (1922). The percentage of all grain size fractions were different for CL and FL ( $\mathrm{T}$ test $-\mathrm{P}<0.05)$. 
Subsequently, roots and aerial parts of plants were carefully washed in distilled water and dried in an oven at $40{ }^{\circ} \mathrm{C}$ for four days until constant weight was achieved. The material was then weighed using a digital scale $(0.001 \mathrm{~g})$ to determine dry biomass of roots and shoots, and to later calculate the root/shoot biomass ratio (biomass of roots divided by the biomass of shoots). After weighing, plants were pulverized in a cutting mill and sent for chemical analysis by the Laboratório de Geoquímica at the Universidade Federal de Ouro Preto.

Plant tissues were solubilized in a solution of nitric acid and hydrogen peroxide with the aid of a microwave (Gonzalez et al. 2009). After solubilization, the concentration of chemical elements was evaluated using an Agilent 725 Inductively Coupled Plasma-Optical Emission Spectrometer (ICP-OES). The certified material NIST SRM 1515 (Apple leaves, National Institute of Standards and Technology, Gaithersburg, USA) was used to monitor the quality of the ICP-OES analysis. Recoveries were satisfactory for the analyzed elements (80-120\%).

\section{Statistical analyses}

The existence of significant effects of the variables grain size and addition of topsoil, and the interaction between them, on the parameters measured were evaluated by a
General Linear Model (GLM) followed by the Tukey test, in cases where GLM showed significant differences among data. The parameters measured were root volume, root surface area, root length, dry biomass, root/shoot biomass ratio and concentration of chemical elements. Data on dry biomass, root/shoot biomass ratio, root volume, root length and concentration of some of the chemical elements in roots $(\mathrm{Ni}, \mathrm{V}, \mathrm{K}$ and $\mathrm{Na}$ ) and shoots $(\mathrm{Cr}, \mathrm{Ni}, \mathrm{Y}, \mathrm{Al}, \mathrm{Fe}, \mathrm{Na}, \mathrm{P}$ and $S$ ) did not meet normality requirements (KolmogorovSmirnov test) and/or variance homogeneity (Levene's test). In these cases, data were transformed by means of Box-Cox transformation. All statistical tests were performed with $5 \%$ significance using MINITAB $18^{\circledR}$ statistical software.

\section{Results}

All plants of the four treatments survived until the end of the experiment and two CLT plants started flowering. The addition of topsoil to the laterite substrate increased Periandra mediterranea biomass (Fig. 1). The plants of the CLT and FLT treatments possessed, respectively, average dry biomass 46 and $151 \%$ higher than the biomass of $\mathrm{CL}$ and FL treatments. Additionally, it was observed that plants cultivated without the addition of topsoil had higher biomass production in CL, with mean dry biomass $140 \%$ higher than plants grown in FL. Plants of all treatments
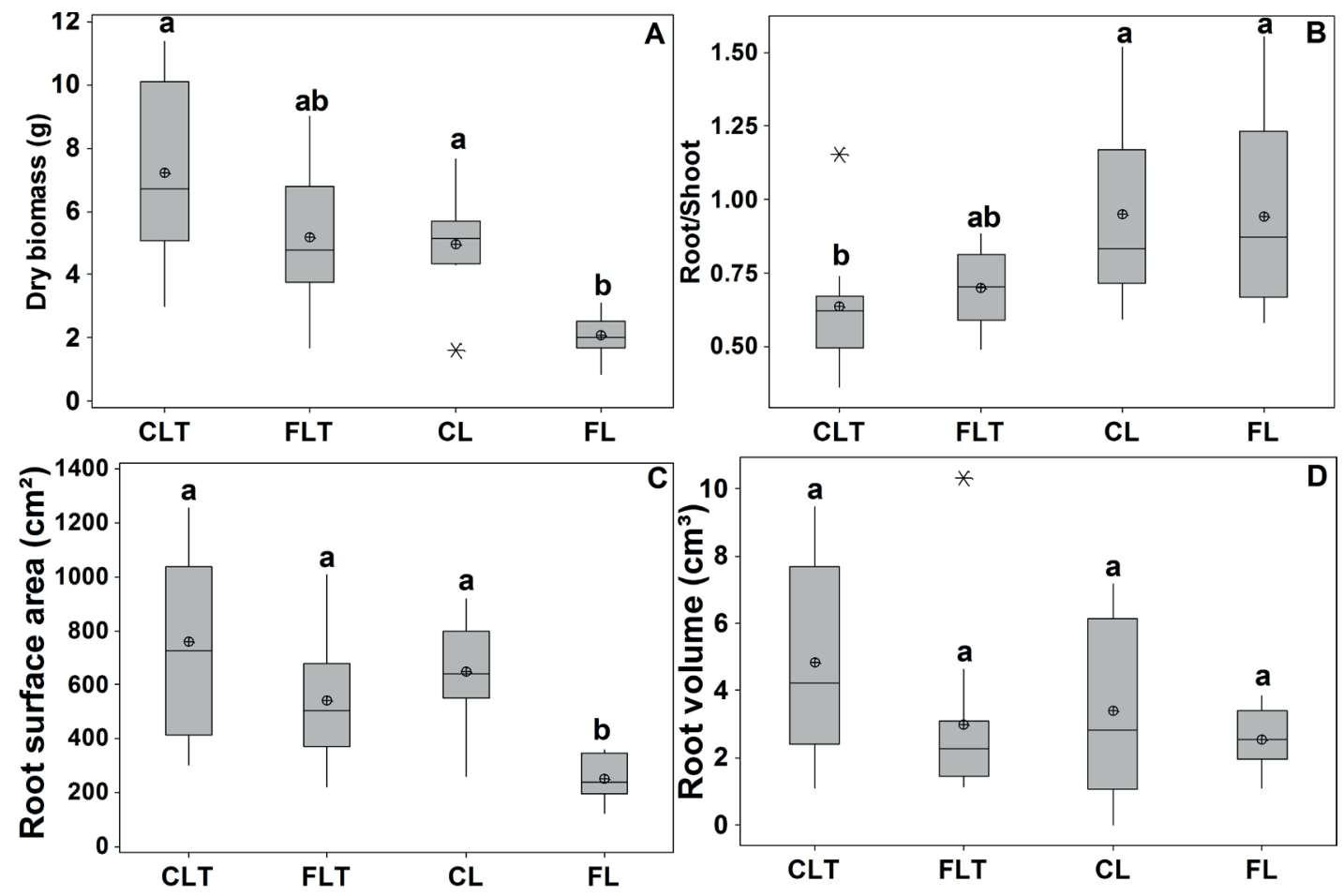

Figure 1. Box plot of: A. plant dry biomass; B. root/shoot ratio; C. root surface area and D. root volume measured in $P$. mediterranea grown in coarse laterite (CL), fine laterite (FL), coarse laterite with topsoil (CLT) and fine laterite with topsoil (FLT). Legend: The bases of rectangles correspond to the first and third quartiles of data distribution; lines and circles within rectangles correspond, respectively, to medians and means, bars represent the maximum and minimum values and asterisks correspond to outliers. Different letters indicate significant differences among treatments $(\mathrm{P}<0.05)$. 
exhibited higher biomass allocation to the aerial part, and plants of treatments with the addition of topsoil had lower root/shoot ratios than plants of substrates with the same grain size but without the addition of topsoil. For root surface area, FL plants had statistically lower values than those for CL, CLT and FLT plants, but there was no significant difference among treatments in root volume (Fig. 1).

The lengths of roots in FL, FLT, CL and CLT were 25, 46, 61 and $68 \mathrm{~m}$, respectively, with only FL being significantly different from the others. Plants of the different treatments possessed similar proportions of roots with diameters less than $0.5 \mathrm{~mm}$ with about $85 \%$ of the root length. In treatments with the addition of topsoil (CLT and FLT), all plants possessed symbiotic nodules, indicating association with nitrogen-fixing bacteria, while in the CL and FL treatments only $50 \%$ of plants possessed symbiotic nodules.

Of all the parameters analyzed, an interaction among treatments was observed only for the concentrations of Barium and Cobalt in shoot tissue. Few chemical elements exhibited significant differences in concentration among treatments, especially in the root system (Tab. 2). It was also observed that there was greater accumulation of toxic elements or elements present in high concentrations in the soil in the root system (Tab. 2).

\section{Discussion}

The survival of all plants and the adequate growth of $P$. mediterranea in substrate characterized as poor in nutrients and with high concentrations of some toxic elements show that $P$. mediterranea has potential for use in the restoration of degraded areas. Thus this species can be used to replace or reduce the use of exotic and invasive species, which has caused much damage to rupestrian grasslands (Barbosa et al. 2010; Hilário et al. 2011; Fernandes et al. 2015; 2016).

Although the growth of $P$. mediterranea is slow, the biomass of the individuals evaluated in this study is similar to that obtained for other native legumes of rupestrian grasslands growing on dystrophic substrates (Negreiros et al. 2009). In addition, P. mediterranea has morphological characteristics advantageous to revegetation of degraded areas, such as scandent growth and shrub habit (Funch \& Barroso 1999), which minimizes shading. This facilitates the germination and establishment of other species, contributing to diversity and succession in the area being revegetated. Some legumes commonly used in revegetation of degraded areas usually exhibit aggressive and widespread growth, which contributes to rapid soil cover. As a consequence, these species may hinder the establishment

Table 2. Mean values for concentrations $\left(\mathrm{mg} \mathrm{kg}^{-1}\right)$ of chemical elements present in roots and shoots of $P$. mediterranea grown on coarse laterite (CL), fine laterite (FL), coarse laterite with topsoil (CLT)and fine laterite with topsoil (FLT). Mean \pm standard deviation.

\begin{tabular}{|c|c|c|c|c|c|c|c|c|}
\hline & \multicolumn{4}{|c|}{ Root } & \multicolumn{4}{|c|}{ Shoot } \\
\hline & CLT & FLT & $\mathrm{CL}$ & FL & CLT & FLT & $\mathrm{CL}$ & $\mathbf{F L}$ \\
\hline \multicolumn{9}{|c|}{ Macronutrients } \\
\hline $\mathrm{Ca}$ & $2572 \pm 614 a$ & $1968 \pm 568 \mathrm{a}$ & $3003 \pm 539 a$ & $2612 \pm 385 a$ & $4960 \pm 556 b$ & $4677 \pm 726 b$ & $6699 \pm 892 a$ & $6739 \pm 925 a$ \\
\hline K & $2035 \pm 1135 a$ & $1447 \pm 660 \mathrm{a}$ & $1735 \pm 604 a$ & $1997 \pm 1230 \mathrm{a}$ & $6648 \pm 1354 a$ & $4322 \pm 871 b$ & $6495 \pm 1211 \mathrm{ab}$ & $6584 \pm 801 \mathrm{a}$ \\
\hline $\mathrm{Mg}$ & $857 \pm 91 \mathrm{a}$ & $789 \pm 171 \mathrm{a}$ & $702 \pm 118 a$ & $838 \pm 168 a$ & $1516 \pm 519 a$ & $964 \pm 248 a$ & $1561 \pm 300 \mathrm{a}$ & $1467 \pm 193 a$ \\
\hline $\mathrm{P}$ & $292 \pm 121 a$ & $296 \pm 67 a$ & $212 \pm 73 a$ & $180 \pm 40 a$ & $569 \pm 187 a$ & $411 \pm 63 a$ & $406 \pm 55 a$ & $401 \pm 77 a$ \\
\hline$S$ & $1338 \pm 509 a$ & $1197 \pm 201 \mathrm{a}$ & $1199 \pm 344 a$ & $1154 \pm 234 a$ & $2710 \pm 1347 a$ & $1126 \pm 283 b$ & $2458 \pm 895 a$ & $1823 \pm 549 a b$ \\
\hline \multicolumn{9}{|c|}{ Micronutrients } \\
\hline $\mathrm{Cu}$ & $25.8 \pm 5.5 a$ & $24.9 \pm 3.2 \mathrm{a}$ & $24.8 \pm 5.1 \mathrm{a}$ & $25.7 \pm 4.7 \mathrm{a}$ & $16.0 \pm 4.2 \mathrm{~b}$ & $17.0 \pm 5.2 b$ & $34.0 \pm 9.2 \mathrm{a}$ & $28.8 \pm 11.9 \mathrm{ab}$ \\
\hline $\mathrm{Fe}$ & $853 \pm 243 a$ & $1061 \pm 368 \mathrm{a}$ & $886 \pm 94.4 a$ & $954 \pm 259 a$ & $94.2 \pm 32.4 a$ & $141 \pm 99.9 a$ & $120 \pm 28.9 a$ & $129 \pm 31.4 \mathrm{a}$ \\
\hline $\mathrm{Mn}$ & $69.2 \pm 27.1 \mathrm{a}$ & $64.1 \pm 12.2 \mathrm{a}$ & $62.2 \pm 31.2 \mathrm{a}$ & $61.8 \pm 12.2 \mathrm{a}$ & $128 \pm 40.6 a$ & $107 \pm 16.5 \mathrm{a}$ & $136 \pm 35.4 \mathrm{a}$ & $113 \pm 28.7 \mathrm{a}$ \\
\hline $\mathrm{Zn}$ & $400 \pm 80.6 \mathrm{ab}$ & $450 \pm 84 a$ & $352 \pm 77.3 \mathrm{ab}$ & $296 \pm 24.4 b$ & $88.6 \pm 22.3 b$ & $121 \pm 33.7 \mathrm{ab}$ & $156 \pm 15.1 \mathrm{a}$ & $167 \pm 33.7 \mathrm{ab}$ \\
\hline \multicolumn{9}{|c|}{ Non-essential elements } \\
\hline $\mathrm{Al}$ & $573 \pm 150 a$ & $636 \pm 297 a$ & $577 \pm 78.2 \mathrm{a}$ & $517 \pm 175 a$ & $46.5 \pm 14.5 \mathrm{a}$ & $92.1 \pm 68.5 \mathrm{a}$ & $71.6 \pm 18.9 a$ & $74.1 \pm 20.6 \mathrm{a}$ \\
\hline $\mathrm{Ba}$ & $11.4 \pm 1.1 \mathrm{a}$ & $12.4 \pm 2.2 \mathrm{a}$ & $10.1 \pm 1.7 \mathrm{~b}$ & $14.4 \pm 3.3 \mathrm{a}$ & $8.0 \pm 0.8 c$ & $10.8 \pm 3.2 b c$ & $15.8 \pm 1.8 \mathrm{a}$ & $14.4 \pm 1.8 \mathrm{ab}$ \\
\hline $\mathrm{Be}$ & $0.1 \pm 0.004 a$ & $0.1 \pm 0.006 \mathrm{a}$ & $0.1 \pm 0.003 a$ & $0.1 \pm 0.003 a$ & $0.2 \pm 0.02 b$ & $0.2 \pm 0.03 b$ & $0.2 \pm 0.04 \mathrm{a}$ & $0.2 \pm 0.04 \mathrm{ab}$ \\
\hline Co & - & - & - & - & $2.4 \pm 0.3 c$ & $5.2 \pm 0.8 \mathrm{ab}$ & $5.5 \pm 1.1 \mathrm{a}$ & $3.9 \pm 1.2 b c$ \\
\hline $\mathrm{Cr}$ & $2.7 \pm 0.4 \mathrm{a}$ & $3.4 \pm 0.7 a$ & $2.7 \pm 0.6 \mathrm{a}$ & $3.2 \pm 0.6 a$ & $0.6 \pm 0.0 \mathrm{~b}$ & $1.4 \pm 0.2 \mathrm{a}$ & $0.6 \pm 0.03 b$ & $0.6 \pm 0.03 b$ \\
\hline $\mathrm{Ni}$ & $4.0 \pm 0.7 \mathrm{a}$ & $4.8 \pm 1.2 \mathrm{a}$ & $3.5 \pm 0.2 \mathrm{a}$ & $3.6 \pm 0.3 a$ & $7.0 \pm 2.3 b$ & $11.1 \pm 2.0 \mathrm{~b}$ & $15.5 \pm 1.1 \mathrm{a}$ & $13.8 \pm 1.7 \mathrm{ab}$ \\
\hline $\mathrm{Na}$ & $443 \pm 211 a$ & $524 \pm 408 a$ & $339 \pm 259 a$ & $226 \pm 97.6 \mathrm{a}$ & $356 \pm 168 \mathrm{a}$ & $331 \pm 262 \mathrm{a}$ & $192 \pm 75.3 a$ & $208 \pm 86.5 \mathrm{a}$ \\
\hline Sr & $13.1 \pm 1.4 \mathrm{a}$ & $10.8 \pm 1.8 \mathrm{a}$ & $13.0 \pm 1.4 \mathrm{a}$ & $12.3 \pm 1.1 \mathrm{a}$ & $12.2 \pm 1.5 b$ & $12.1 \pm 2.3 b$ & $16.5 \pm 2.4 \mathrm{a}$ & $16.4 \pm 3.3 \mathrm{a}$ \\
\hline $\mathrm{Ti}$ & $9.0 \pm 2.9 a$ & $9.9 \pm 3.8 a$ & $9.1 \pm 1.7 \mathrm{a}$ & $7.2 \pm 2.3 a$ & $1.0 \pm 0.4 \mathrm{a}$ & $1.9 \pm 1.0 \mathrm{a}$ & $1.4 \pm 0.4 \mathrm{a}$ & $1.4 \pm 0.4 \mathrm{a}$ \\
\hline V & $1.8 \pm 0.5 \mathrm{a}$ & $2.1 \pm 0.7 \mathrm{a}$ & $1.8 \pm 0.2 \mathrm{a}$ & $1.7 \pm 0.5 a$ & - & - & - & - \\
\hline Y & - & - & - & - & $0.4 \pm 0.1 \mathrm{a}$ & $0.4 \pm 0.002 a$ & $1.2 \pm 0.2 \mathrm{a}$ & $1.1 \pm 0.6 \mathrm{a}$ \\
\hline
\end{tabular}

Values in the same line followed by different letters indicate significant differences between them $(\mathrm{P}<0.05)$. $(-)$ indicates values below the limit quantification of the ICP-OES equipment. 
and development of other species, and may require their removal or management (Chapman et al. 1996; Podadera et al. 2015).

Periandra mediterranea exhibited high biomass allocation to the shoot, which also occurs with other native species of shallow and stony soil environments, in which root growth is difficult (Negreiros et al. 2009). Nevertheless, under natural conditions the species is fairly capable of re-growing after burning (Hoffmann \& Solbrig 2003; Neves \& Conceição 2010; Figueira et al. 2016). This feature is particularly relevant for revegetation of degraded areas of rupestrian grasslands, in which fires are common (Figueira et al. 2016).

The fact that the CL treatment plants had about $140 \%$ more biomass than the FL treatment plants is probably related to the greater porosity and aeration, and lower density, of the coarse substrate (Buchanan et al. 2010). Together these factors contribute to better root growth (Wang et al. 2008; Chapman et al. 2012) and the investment in fine roots (Materechera et al. 1991; Sarquis et al. 1991). In fact, it was observed that CL plants yielded a higher root surface area/root volume ratio than FL plants, which indicates that they had a higher proportion of fine roots (Fig. 1). A higher proportion of fine roots promotes greater interaction between the root system and the substrate, increasing nutrient uptake and improving substrate containment (Burylo et al. 2012). In addition to the better growth of $P$. mediterranea in the coarse substrate, the use of substrate with a predominance of coarser fractions in the recovery of degraded areas requires less financial investment in preparation (Machado et al. 2013). The coarser the substrate, the better the rainwater percolation (Figueiredo 2014), which contributes to water recharge and reduction of surface transport, a common problem in areas degraded by mining because it makes plant establishment more difficult (Craw et al. 2007). On the other hand, faster water percolation through the substrate also reduces soil water availability during periods of low rainfall. In field experiments using a substrate with similar physical and chemical characteristics to CL evaluated in this study, the substrate was found to maintain an average matric potential of around - $0.023 \mathrm{MPa}$ with only $45 \mathrm{~mm}$ of rain distributed over 27 days. In addition, the substrate evaluated in the field allowed the growth of Eremanthus erythropappus, a native species of rupestrian grasslands, throughout all seasons (Figueiredo et al. 2015).

The addition of topsoil promoted biomass gain in relation to treatments using substrates of the same grain size (Fig. 1). Although the addition of topsoil may have contributed nutrients to plants, it is assumed that the small volume added (only $0.42 \%$ of lateritic substrate) is not the reason for the increased growth of $P$. mediterranea in topsoil treatments. According to Benites et al. (2007), Schaefer et al. (2015) and Schaefer et al. (2016), the soil (even the topsoil) of ferruginous rupestrian grasslands is recognized as dystrophic.
It is possible that the increased plant growth in treatments with topsoil is related to the presence of microorganisms. In these treatments, the association of plants with nitrogen-fixing bacteria was observed, whereas in the other treatments it occurred in only half of the plants. Although not quantified in this study, it is known that P. mediterranea associates with arbuscular mycorrhizal fungi (Lima 2014). In absolute values, plants of CLT and FLT treatments had higher phosphorus concentrations in comparison to plants in treatments without the addition of topsoil (Tab. 2).

The use of small portions of surface soil as a source of microorganisms that aid plant growth is a facilitatory tool for the revegetation of degraded where the volume of remaining topsoil is not sufficient to cover the entire area. In addition, the use of small portions of topsoil over the long term, may contribute to the nitrogen enrichment of the substrate, which is a major limitation to plant development in degraded areas (Bradshaw 1997).

In contrast to the lack of macronutrients in the substrate (Tab. 1), P. mediterranea possessed concentrations of macroand micronutrients within ranges considered average for these elements in plants (Larcher 2000; Kabata-Pendias 2011). In addition, P. mediterranea did not possess above average concentrations of potentially toxic elements such as $\mathrm{Al}, \mathrm{V}, \mathrm{Fe}$ and $\mathrm{Cr}$, which were found at higher concentrations in the studied substrates than those considered average for these elements in soils. Aluminium and V concentrations exceeded average values by about $300 \%$, while Fe and $\mathrm{Cr}$ concentrations were about $500 \%$ higher (Shanker et al. 2005; Kabata-Pendias 2011). Periandra mediterranea tolerates high concentrations of these elements by excluding and accumulating them preferentially in the root system. For example, $\mathrm{Al}, \mathrm{Fe}$ and $\mathrm{Cr}$ concentrations were found to be, respectively, twelve, nine and six times higher in the root system when compared to those found in shoots (Tab. 2). Despite the high concentration of $\mathrm{Al}$ and $\mathrm{Cr}$, which are elements known to be detrimental to root development of many cultivated species, (Ma et al. 2001; Shanker et al. 2005; Vernay et al. 2007), no visually damage was observed in $P$. mediterranea roots.

Litter decomposition is known to be relevant to the availability of chemical elements in the soil (Rustad \& Cronan 1995). Therefore, plants like P. mediterranea, which colonize degraded substrates, accumulate potentially toxic elements preferentially in the roots, yet possess concentrations of nutrients in shoots within ranges of average values, and thus do not enrich the superficial layer of the soil with toxic elements. In addition, plants capable of growing on substrates rich in toxic elements, yet possess concentrations of these elements in their aerial parts within average ranges, do not increase the availability of such elements to fauna and environment, which could affect local ecological relationships (Mehdawi et al. 2011; Mehdawi \& Pilon-Smits 2012). 
Under the conditions evaluated in the present study, the use of substrate from degraded areas with the predominance of coarser grain size fractions was more favorable for the growth of $P$. mediterranea. In addition, simple low-cost procedures, such as the addition of small amounts of topsoil as a source of microorganisms for the degraded substrate, can significantly increase plant growth and may be a good alternative when topsoil availability is limited.

Finally, this study showed that P. mediterranea has potential application in the revegetation of degraded areas, with easy establishment and growth in substrates from degraded areas contributing to their fertility. If the results obtained with $P$. mediterranea are confirmed in field evaluations, it is possible that this species could be used to replace other exotic and invasive legumes commonly used in the revegetation of degraded areas in Brazil, and which have caused problems such as limitations to ecological succession and the invasion of adjacent areas (Hilário et al. 2011; Fernandes et al. 2015).

\section{Acknowledgements}

We thank Prof. José Badini Herbarium, the "Jorge Luiz da Silva" Botanical Garden and the Laboratory of Plant Ecophysiology (DEBIO) and the Laboratory of Geochemistry (DEGEO) of the Federal University of Ouro Preto for providing infrastructure and assistance in the development of this study. This study was supported by UFOP and FAPEMIG.

\section{References}

Alvares CA, Stape JL, Sentelhas PC, Gonçalves JLM, Sparovek G. 2014. Koppen's climate classification map for Brazil. Meteorologische Zeitschrift 22:711-728.

Barbosa NPU, Fernandes GW, Carneiro MAA, Júnior LAC. 2010. Distribution of non-native invasive species and soil properties in proximity to paved roads and unpaved roads in a quartzitic mountainous grassland of southeastern Brazil (rupestrian fields). Biological Invasions 12: 3745-3755.

Benites VM, Schaefer CEGR, Simas FNB, Santos HG. 2007. Soils associated with rock outcrops in the Brazilian mountain ranges Mantiqueira and Espinhaço. Revista Brasileira de Botânica 30: 569-577.

Bradshaw A. 1997. Restoration of mined lands-using natural processes. Ecological Enginnering 8: 255-269.

Buchanan SJ, So HB, Kopittke PM, Menzies NW. 2010. Influence of texture in bauxite residues on void ratio, water holding characteristics, and penetration resistance. Geoderma 158: 421-426.

Burylo M, Rey F, Mathys N, Dutoit T. 2012. Plant root traits affecting the resistance of soils to concentrated flow erosion. Earth Surf Process Landforms 37: 1463-1470.

Bustamante MMC, Brito DQ, Kozovits AR, et al. 2012. Effects of nutrient additions on plant biomass and diversity of the herbaceous-subshrub layer of a Brazilian savanna (Cerrado). Plant Ecology 213: 795-808.

Chapman N, Miller AJ, Lindsey K, Whalley WR. 2012. Roots, water, and nutrient acquisition: let's get physical. Trends in Plant Science 17: 701-710.

Chapman R, Collins J, Younger A. 1996. Control of legumes in a species rich meadow re-created on land restored after opencast coal mining. Restoration Ecology 4: 407-411.
COPAM - Conselho Estadual de Política Ambiental. 2008. Deliberação normativa número 127. Estabelece diretrizes e procedimentos para avaliação ambiental da fase de fechamento de mina. Belo Horizonte, COPAM. http://www.siam.mg.gov.br/sla/download. pdf?idNorma=8732. 27 Set. 2017.

Craw D, Rufalt CG, Hammit S, Clearwater SG, Smith CM. 2007. Geological controls on natural ecosystem recovery on mine waste in southern New Zealand. Environmental Geology 51: 1389-1400.

Embrapa - Empresa Brasileira de Pesquisa Agropecuária. 1997. Manual de métodos de análise de solos. 2nd. edn. Rio de Janeiro, Embrapa.

Fernandes GW, Barbosa NPU, Negreiros D, Paglia AP. 2014. Challenges for the conservation of vanishing megadiverse rupestrian grasslands. Natureza e Conservação 12: 162-165.

Fernandes GW, Santos R, Barbosa NPU, Almeida HA, Carvalho V, Angrisano P. 2015. Ocorrência de plantas não nativas e exóticas em áreas restauradas de campos rupestres. Planta Daninha 33: 463-482.

Fernandes GW, Toma TSP, Angrisano P, Overbeck G. 2016. Challenges in the restoration of quartzitic and ironstone rupestrian grasslands. In: Fernandes GW. (ed.) Ecology and conservation of mountaintop grasslands in Brazil. Cham, Springer. p. 449-477.

Figueira JEC, Ribeiro KT, Ribeiro MC, et al. 2016. Fire in rupestrian grasslands: plant response and management. In: Fernandes GW. (ed.) Ecology and conservation of mountaintop grasslands in Brazil. Cham, Springer. p. 415-468.

Figueiredo MA. 2014. Efeito de diferentes granulometrias de substrato laterítico nas relações geoquímicas, hídricas e no crescimento de Eremanthus erythropappus em uma área degradada pela mineração. PhD Thesis, Universidade Federal de Ouro Preto, Ouro Preto.

Figueiredo MA, Baêta HE, Kozovits AR. 2012. Germination of native grasses with potential application in the recovery of degraded areas in Quadrilátero Ferrífero, Brasil. Biota Neotropica 12: 118-123.

Figueiredo MA, Leite MGP, Kozovits AR. 2015. Influence of soil texture on nutrients and potentially hazardous elements in Eremanthus erythropappus. International Journal of Phytoremediation 18: 487-493.

Funch LS, Barroso GM. 1999. Revisão taxonômica do gênero Periandra Mart. ex Benth. (Leguminosae, Papilionoideae, Phaseoleae). Revista Brasileira de Botânica 22: 339-356.

Garcia LC, Barros FDV, Lemos P. 2006. Comportamento germinativo de duas espécies de canga ferrífera: Baccharis retusa DC. (Asteraceae) e Tibouchina multiflora Cogn. (Melastomataceae). Acta Botanica Brasilica 20: $443-448$.

Gonzalez MH, Souza GB, Oliveira RV, et al. 2009. Microwave-assisted digestion procedures for biological samples with diluted nitric acid: Identification of reaction products. Talanta 79: 396-401.

Groom A. 2012. Periandra mediterranea. The IUCN red list of threatened species 2012: e.T19892132A20127078. http://dx.doi.org/ 10.2305/ IUCN.UK.2012.RLTS.T19892132A20127078.en. 27 Set. 2017.

Hilário RR, Castro SAB, Ker FTO, Fernandes G. 2011. Unespected effects of Pigeon-Peas (Cajanus cajan) in the restoration of rupestrian fields. Planta Daninha 29: 717-723.

Hoffmann WA, Solbrig OT. 2003. The role of topkill in the differential response of savanna woody species to fire. Forest Ecology and Management 180: 273-286.

Kabata-Pendias A. 2011. Trace elements in soils and plants. 4th. edn. London, Taylor and Francis.

Kolbek J, Alves RJV. 2008. Impacts of cattle, fire and wind in rocky savannas, Southeastern Brazil. Acta Universitatis Carolinae 22: 111-130.

Lambers H, Martinoia E, Renton M. 2015. Plant adaptations to severely phosphorus-impoverished soils. Current Opinion in Plant Biology 25: 23-31.

Larcher W. 2000. Ecofisiologia Vegetal. São Carlos, Rima Artes e Textos. Lima CT, Furtini Neto AE, Giulietti AM, Mota NFO, Braga RP, Viana PL. 2016. Guia de plantas para a recuperação de áreas degradadas nas cangas do Quadrilátero Ferrífero de Minas Gerais. Fortaleza, Fundação Brasil Cidadão.

Lima LL. 2014. Diversidade e aplicação de fungos micorrízicos arbusculares em Complexo Ferruginoso, no Quadrilátero Ferrífero, Minas Gerais. $\mathrm{PhD}$ Thesis, Universidade Federal de Ouro Preto, Ouro Preto. 


\section{Growing Periandra mediterranea on post-mining substrate: native Fabaceae with potential for revegetation of degraded rupestrian grasslands in Brazil}

Ma JF, Ryan PR, Delhaize E. 2001. Aluminium tolerance in plants and the complexing role of organic acids. Trends in Plant Science 6: 273-278.

Machado NADM, Leite MGP, Figueiredo MA, Kozovits AR. 2013. Growing Eremanthus erythropappus in crushed laterite: A promising alternative to topsoil for bauxite-mine revegetation. Journal of Environmental Management 129: 149-156.

Madejón P, Murillo JM, Marañón T, Cabrera F, Soriano MA. 2003. Trace element and nutrient accumulation in sunflower plants two years after the Aznalcollar mine spill. The Science of the Total Environment 307: 239-257.

Materechera SA, Dexter AR, Alston AM. 1991. Penetration of very strong soils by seedling roots of different plant species. Plant Soil 135: 31-41.

Mehdawi AF, Pilon-Smits EAH. 2012. Ecological aspects of plant selenium hyperaccumulation. Plant Biology 14: 1-10.

Mehdawi AF, Quinn CF, Pilon-Smits EAH. 2011. Effects of selenium hyperaccumulation on plant - plant interactions: evidence for elemental allelopathy? New Phytology 191: 120-131.

Menéndez E, Bahena MHR, Carro L, et al. 2016. Paenibacillus periandrae sp. nov., isolated from nodules of Periandra mediterranea. International Journal of Systematic and Evolutionary Microbiology 66: 1838-1843.

Messias MCTB, Carmo FF. 2015. Flora e vegetação em substratos ferruginosos do sudeste do Quadrilátero Ferrífero. In: Carmo FF, Kamino LHY. (eds.) Geossistemas Ferruginosos do Brasil: áreas prioritárias para conservação da diversidade geológica e biológica. Patrimônio cultural e serviços ambientais. Belo Horizonte, $3 i$ editora. p. 335-360.

Messias MCTB, Leite MGP, Meira-Neto JAA, Kozovits AR. 2012. Fitossociologia de campos rupestres quartzíticos e ferruginosos no Quadrilátero Ferrífero, Minas Gerais. Acta Botanica Brasilica 26: 230-242.

Messias MCTB, Leite MGP, Meira-Neto JAA, Kozovits AR, Tavares R. 2013. Soil-Vegetation Relationship in Quartzitic and Ferruginous Brazilian rocky outcrops. Folia Geobotânica 48: 509-521.

Mourão A, Stehmann JR. 2007. Levantamento da flora do campo rupestre sobre canga hematítica couraçada remanescente na mina do Brucutu, Barão de Cocais, Minas Gerais, Brasil. Rodriguésia 58: 775-786.

Moutte J. 2009. Analysis of geological materials by ICPAES in Department of Geology, Saint Etienne School of Mines. http://www.emse. fr/ moutte/enplasma/index.htm. 04 Aug. 2017.

Myers N, Mittemeier RA, Mittemeier CG, Fonseca GAB, Kent J. 2000. Biodiversity hotspots for conservation priorities. Nature 403: 853-858.

Negreiros D, Fernandes GW, Silveira FAO, Chalub C. 2009. Seedling growth and biomass allocation of endemic and threatened shrubs of rupestrian fields. Acta Oecologica 35: 301-310.

Neves SPS, Conceição AA. 2010. Campo rupestre recém-queimado na Chapada Diamantina, Bahia, Brasil: plantas de rebrota e sementes, com espécies endêmicas na rocha. Acta Botanica Brasilica 24: 697-707.

Oliveira RB, Godoy SAP. 2007. Composição florística dos afloramentos rochosos do Morro do Forno, Altinópolis, São Paulo. Biota Neotropica 7: 37-47.

Oliveira RS, Abrahão A, Pereira C, et al. 2016. Ecophysiology of Campos Rupestres plants. In: Fernandes GW. (ed.) Ecology and conservation of mountaintop grasslands in Brazil. Cham, Springer. p. 227-272.

Pereira BMR, Silva BP, Pereira NA, Parente JP. 2000. Anti-inflammatory and immunologically active polysaccharides of Periandra mediterranea. Phytochemistry 54: 409-413.

Podadera DS, Engel VL, Parrota JA, Machado DL, Sato LM, Durigan G. 2015. Influence of removal of a non-native tree species Mimosa caesalpiniifolia Benth. on the regenerating plant communities in a tropical semideciduous forest under restoration in Brazil. Environmental Management 56: 1148-1158.
Queiroz LP. 2016. Periandra. In: Lista de Espécies da Flora do Brasil. Rio de Janeiro, Jardim Botânico do Rio de Janeiro. http://floradobrasil. jbrj.gov.br/jabot/FichaPublicaTaxonUC/FichaPublicaTaxonUC. do?id=FB29812. 27 Set. 2017.

Rodrigues ERS, Silveira FAO. 2013. Seed germination requirements of Trembleya laniflora (Melastomataceae), an endemic species from neotropical montane rocky savannas. Plant Species Biology 28: 165168.

Rustad LE, Cronan CS. 1995. Biogeochemical controls on aluminum chemistry in the O horizon of a red spruce (Picea rubens Sarg.) stand in central Maine USA. Biogeochemistry 29:107-129.

Sarquis J, Jordan WR, Morgan PW. 1991. Ethylene evolution from maize (Zea mays $\mathrm{L}$ ) seedling roots and shoots in response to mechanical impedance. Plant Physiology 96: 1171-1177.

Schaefer CEGR, Cândido HG, Corrêa GR, et al. 2015. Solos desenvolvidos sobre canga ferruginosa no Brasil: uma revisão crítica e papel ecológico de termiteiros. In: Carmo FF, Kamino LHY. (orgs.) Geossistemas Ferruginosos do Brasil: áreas prioritárias para conservação da diversidade geológica e biológica. Patrimônio cultural e serviços ambientais. Belo Horizonte, 3i editora. p. 77-102.

Schaefer CEGR, Cândido HG, Corrêa GR, Nunes JA, Arruda DM. 2016. Soils associated with rupestrian grasslands. In: Fernandes GW. (ed.) Ecology and conservation of mountaintop grasslands in Brazil. Cham, Springer. p. 55-69.

Shanker AK, Cervantes C, Loza-Tavera H, Avudainayagam S. 2005. Chromium toxicity in plants. Environment International 31: 739-753.

Silva ED, Martins AB. 2013. Leguminosae-Papilionoideae na Serra do Cabral, MG, Brasil. Hoehnea 40: 293-314.

Silveira FAO, Negreiros D, Barbosa NPU, et al. 2015. Ecology and evolution of plant diversity in the endangered campo rupestre: a neglected conservation priority. Plant Soil 403: 129-152.

Sonter LJ, Barrett DJ, Soares-Filho BS. 2014. Offsetting the impacts of mining to achieve no net loss of native vegetation. Conservation Biology 28: 1068-1076.

Stradic S, Buisson E, Negreiros D, Campagne P, Fernandes GW. 2014a. The role of native woody species in the restoration of Campos Rupestres in quarries. Applied Vegetation Science 17: 109-120.

Stradic S, Buisson E, Fernandes GW. 2014b. Restoration of Neotropical grasslands degraded by quarrying using hay transfer. Applied Vegetation Science 17: 482-492.

Stradic S, Silveira FAO, Buisson E, Cazelles K, Carvalho V, Fernandes GW. 2015. Diversity of germination strategies and seed dormancy in herbaceous species of campo rupestre grasslands. Austral Ecology 40: 537-546.

Veldman JW, Buisson E, Durigan G, et al. 2015. Toward an old-growth concept for grasslands, savannas, and woodlands. Frontier Ecology Environment 13: 154-162.

Vernay P, Gauthier-Moussard C, Hitmi A. 2007. Interaction of bioaccumulation of heavy metal chromium with water relation, mineral nutrition and photosynthesis in developed leaves of Lolium perenne L. Chemosphere 68: 1563-1575.

Viana PL, Lombardi JA. 2006. Florística e caracterização dos campos rupestres sobre canga na serra da Calçada, Minas Gerais, Brasil. Rodriguésia 58: 159-177.

Vincent RC, Meguro M. 2008. Influence of soil properties on the abundance of plant species in ferruginous rocky soils vegetation, southeastern Brazil. Brazilian Journal of Botany 31: 377-388.

Wang X, Liu Y, Zeng G, et al. 2008. Pedological characteristics of Mn mine tailings and metal accumulation by native plants. Chemosphere 72: 1260-1266.

Wentworth CK. 1922. A scale of grade and class terms for clastic sediments. Geological Survey 30: 377-392. 